IIUC STUDIES

ISSN 1813-7733

Vol.-12 December 2015

(P. 127-138)

\title{
Satisfaction towards Banking Profession: A Comparative Study on Male and Female Executives
}

\begin{abstract}
Mohd. Kamal Uddin ${ }^{1}$, Mohammad. Jonaed Kabir ${ }^{2}$
ABSTRACT: Banking sector in Bangladesh is recruiting women more in number than ever before. Women are now viewed by planners and policy makers as equal partners in the process of development and great contributors to state economy. Banks, as development catalysts, need to evaluate both the male and female employees, in a timely manner to enhance their effort to work. This paper attempts to evaluate job satisfaction of bank officers considering sex differences to determine a fruitful comparison. The research work was conducted through JDI administered questionnaire on a sample of 210 employees from six banks (Two public and four private banks). A popular measure of job satisfaction - the Job Descriptive Index (JDI) - measure satisfaction in terms of five aspects of a person's job: pay, promotion, supervision, the work itself and co-workers (Hellriegel and Woodman, 1995). As the two gender groups were not normally distributed, a Mann-Whitney $U$ test was applied to test relationship between gender and job satisfaction with each facet. The findings of the study show that higher satisfaction among females for three of the five job facets while male officers dominate the rest two factors. The present study attempts to enrich the existing knowledge base in the area of job satisfaction in banking sector adding a new dimension of HRM-issues.
\end{abstract}

Key words: Job satisfaction, Bank Executives, JDI, Mann-

\section{Introduction} Whitney U test.

With the up-rising of the economy of Bangladesh, a dramatic change has been observed in service sectors. Particularly, the expansion in private banking business, along with customized service, has brought higher employment opportunities equally to both male and female graduates. This situation has created an urge to the bank policy makers to identify the basic reasons and brought them into consideration with job satisfaction issue. Job satisfaction is one of the most widely researched areas in organization behavior and human resource management (Okpara, 2006). Extensive study has shown that job satisfaction has a

\footnotetext{
${ }^{1}$ Assistant Professor, Faculty of Business Administration, BGC Trust University Bangladesh,

${ }^{2}$ Assistant Professor, Department of Business Administration, International Islamic University Chittagong.
} 
direct impact on the performance of employees in different levels of profession. There is some evidence in the literature that state moods are related to overall job satisfaction (Roberson L., 1989).

Job satisfaction is the pleasurable emotional state resulting from the perception of one's job (Locke, 1976). It is the function of perceived relationship between what one desires and what he gets along with the importance he puts to such value or perceptions. It is related to employee motivation and performance (Ostroff, 1992). In simple terms, it is the extent to which one feels good about the job. Job satisfaction refers to one's feelings or state of mind regarding the nature of their work (Sharmima Tasnim, 2006). Happy employees are the productive employees. Numerous studies have shown that dissatisfied employees are more likely to quit their jobs or be absent than satisfied employees (e.g., Hackett \& Guion, 1985; Hulin, Roznowski \& Hachiya, 1985; Kohler \& Mathieu, 1993). Moreover, lower job satisfaction tends to have higher absenteeism and turn over (Bullen and Famholtz, 1985).

A popular measure of job satisfaction - the Job Descriptive Index (JDI) measure satisfaction in terms of five aspects of a person's job: pay, promotion, supervision, the work itself and the co-workers. (Hellriegel and Woodman, 1954). When employees are asked to evaluate different facets of their job such as pay, promotion, opportunities, supervision, coworkers, and so forth, the nature of the work itself generally emerges as the most important job facet (Judge \& church, 2000; Jurgenser, 1978). Women who constitute half of the world population have been assigned a secondary status in all religion and culture (Hussain \& Jahed, 2000). However, participation of women in workforce has doubled in the last decade in Bangladesh. Women are accepted and assimilated fast in the banking sector. With their gentleness, patience and courteous nature, they are well-suited to customer oriented banking industry.

Herzberg, et al (1957) observes comparison of job attitudes between men and women is of less interest than a study of the effects of the societal roles of men and women on their attitudes toward job. Hulin and smith (1964) explained that if the sources of correlated bias, such as pay, job level, promotional opportunities, and societal norms, are held constant or partially out, sex differences in job satisfaction will disappear. In our male dominated patriarchal society, workplace is also male dominated and forms a 'male-culture'. In spite of this, feminine traits add to performance in banking job. In such situation, job satisfaction of both male and female bank-executives becomes an important issue that has to be taken care of in order to ensure proper 
motivational policy in achieving ultimate goals of the banking sectors in Bangladesh.

\section{Objectives of the Study}

The objectives identified for the study are as follows:

1. To identify the factors of job satisfaction of male and female bank executives working in private and public banks of Bangladesh.

2. To find out the executives satisfaction level that prevails in nationalized and private banks and thereby make a meaningful comparison between the male and female executives regarding the issue.

3. To attract the attention of the policy makers to be more careful in nurturing this sensitive issue in the banking sector in forming satisfied and happy executives.

\section{Research Methodology}

Variables

Overall satisfaction has been taken as a dependent variable and various other factors like pay, promotion, supervisions, co-workers and work itself etc. are considered as the independent variables to accomplish the purpose of identifying the level of job satisfaction of bank employees and to determine whether a significant difference in terms of gender exists thereof.

\section{Selection of samples}

The population of the study comprised employees of the nationalized and private banks of Bangladesh. Bank employees in this study refer to top executives, senior managers, senior officers and officers (not employees such as peons, guards, cleaners, clerks etc.). A random sample of 220 employees from 26 branches of 06 banks (private \& public) was personally communicated along with a structured close ended questionnaire. Ten questionnaires were found with missing data and filled in an inappropriate manner. For this, these questionnaires were excluded to enhance the validity of this study. The sample for this study was two public and four private banks located in Chittagong, the main port city of Bangladesh. A purposive sampling technique was used to select the organization for greater convenience.

\section{Collection of data and Survey instrument}

This study is primarily based on primary data. Job Descriptive Index was used to develop the close ended questionnaire because it is believed to be the most standardized scale for measuring job satisfaction (Smith, 
Kendall and Hulin 1969). The questionnaire provided the respondents with a set of statement of five important facets of job satisfaction i.e., pay, promotion, supervisors, co-workers and work itself. JDI is a reliable facet measure overtime (Kinicki et al.2002) and applicable across a variety of demographic groups (Golembiewski and Yeager 1978; Jung, Dalessio and Johnson 1986). The respondents were asked to read carefully all the answers to each of the questions related to five facets of job and then mark the response that come closest to their own feeling on a five-point Likert scale. Sample characteristics according to the respondents' gender, working experience in current organization (tenure of service), job position, age group, educational level and marital status are gathered through the demographic part of the questionnaire and summarized in Tables 1, 2, 3, 4, 5 and 6.

Mode of data analysis/ Statistical technique

Non-Parametric Mann-Whitney $U$ test was applied to identify the relationship between job facets and overall job satisfaction and establish comparison between the two opposite gender. On the other hand, bivariate frequency distribution of the respondents according to age, gender, tenure, educational background and working positions in the banks was presented in Tables and discussed in the paper.

\section{Reliability and validity test}

The reliability value of our surveyed data was 0.8021 for variables of job satisfaction. If we compare our reliability value with the standard value of 0.6 as recommended by Bagozzi and Yi's (1988), we find that the scales used by us are sufficiently reliable for data analysis.

\section{Analysis of Findings}

Sample characteristics:

Tables - 1, 2, 3, 4, 5 \& 6 summarize the respondents' socio-demographic characteristics according to the sex, experience, working positions, age, educational qualifications and marital status. A number of the studies in the area have found that those factors had significant impact on the level of satisfaction to the view point of two opposite gender. The respondents' profile is discussed in the following sub-sections.

\section{Gender}

Table-I shows the gender distribution of the respondents. According to Hossain and Jahed (2000), recent trends and inflows of modern banking facilities have emphasized the need of women officers in banking institutions and at present Nationalized commercial Banking sector has about 15 percent of its employees women. The present study holds the 
statement true. In the male-dominated work place (in number), 14.3 percent in surveyed questionnaires came from women portion of the workforce.

\section{Job experience}

Experience is an important variable for efficiency and attitude towards work. The experiences of the respondents were computed with reference to years in the present bank organization. This is shown in Table - 2 where it is seen that maximum numbers of executives (both male and female) have 1 to 5 years of banking service experience. Next to them, 6 to 10 years of experienced bank service holders made quick responses to the distributed questionnaire.

\section{Respondents' working position}

Satisfaction may also come from the post an employee holds in an organization. Table - 3 shows the respondents' working positions in banks. No female has been found in Executive or Director Level while maximum females are found at Officer and Junior officer Level. The opposite picture is found in case of their male-counterpart.

\section{Age structure}

In Table - 4, most of the respondents belong to the mid-age group (25-35 years) for both the male and female bank officers The tabulated data thereby indicate that the bank professionals are predominantly young persons.

\section{Educational background}

As natural, the average education background for both male and female respondents of the sample is high. Most of them are post-graduate. A few of them have higher degrees like MBM, Additional Banking Diploma, Post Graduate Diploma or Foreign degrees. The table - 5 shows it clearly.

\section{Marital status}

Overwhelming majority of the female respondents is married and the opposite picture prevails in case of male respondents as shown in Table 6 . It is assumed the marital status of the bank officers is the quite a reflection of our societal and cultural norms and values.

\section{Analysis of statistical findings}

The descriptive findings show that respondents were most satisfied with the job-itself (banking profession), but less satisfied with monetary benefits (pay/salary), interpersonal relation with colleagues and supervisors and with promotional opportunities. Table - 7 explains the 
overall respondents' view through percentage distribution between the two individual dimensions - male and female bank service.

$$
\text { i. Pay }
$$

The pay needs to be fair, equitable and adequate reflecting seniority, experience, effort and other work-related traits. It is believed that insufficient pay or perceived inequitable underpay is more decisive determinant of dissatisfaction; sufficient or fair pay is of satisfaction (Organ 1982). The more important source of dissatisfaction for the nationalized bank employees is their inequitable and under pay. Although the private banks offer attractive pay to their employees, this finding is not consistent with the review. It is also observed, although both the sex expressed their utmost discontent on pay range, female executives seem to be less dissatisfied with pay than their male counterpart. The study found that $8.2 \%$ female respondents were highly satisfied with pay whereas only $7.5 \%$ male-respondents did so and $29.3 \%$ male-respondents were highly disappointed at pay whereas only 28.5\% female-respondents did so.

\section{ii. Promotion}

The opportunities for promotion have been found to influence job satisfaction significantly ( Significance two tailed value is 0.006 nearest to the p-value of 0.000, shown in the 'Promotion' Column of Table - 8). But promotional opportunities seem to have a varying effect on job satisfaction. This is because promotions take a number of different forms and have a variety of accompanying rewards (Siddiqui 1993). Promotion can also be termed as reward / recognition for contributions made by employees. Regarding opportunities for advancement to senior position in banking sector, both the male and female executives expressed their discontent. Male executives were found to be more dissatisfied than the females regarding this issue. The study found that $28.8 \%$ male respondents were highly dissatisfied while $27.5 \%$ female did so and $13.5 \%$ female were highly satisfied with the advancement policy of bank-organization while only $10.4 \%$ male did so.

iii. Supervision

The relationship between the first line supervisors and the individual workman is of more importance in determining the attitude, morale, general happiness, efficiency of that employee than any other single factor (Putnam 1930). Table - 7 shows that most of respondents thought that the quality of supervision in their workplace was not up to their expected levels. Present study found that $15.5 \%$ male respondents were 
highly satisfied with the supervisors' skill where as only $13.2 \%$ female did so.

iv. Interpersonal relation with co-workers

Friendly and co-operative co-workers are a modest source of job satisfaction to individual employees. The work group serves as a source of support, comfort, advice and assistance to the individual employees. A number of research studies have shown that social relationships at work are a great source of job satisfaction to a majority of employees in different occupations (Mustafa and Sylvia 1976). The findings of the study show that male bank executives seem to be more friendly and cooperative than their opposite counterpart in all of the five points in Likert's scale. Among the male respondents, 16.2\% highly satisfied, $17.2 \%$ satisfied and $20.3 \%$ are somewhat satisfied with their colleagues. On the other hand, among the female executives, $15 \%$ highly satisfied, $16.3 \%$ satisfied and $19.3 \%$ are somewhat satisfied.

\section{v. Content of work}

The contents of work like job fascination, social recognition, job security, extra job opportunities etc. have important impact on one's job satisfaction. The work itself must be mentally challenging, with which individual can cope successfully and find interest in and which is not tiring physically or mentally. The collective opinion of the private and public bank employees (both male and female) regarding their profession indicated that they found their work to be interesting, challenging and socially respectable. The present study holds the above statement true. Both the groups of the respondents are quite satisfied with their job. The female executives were found more safe and satisfied than their male counterpart. Among the female respondents, $27.5 \%$ are highly satisfied, $25.4 \%$ satisfied and $22.1 \%$ are somewhat satisfied. On the other hand, among the male respondents, $25.2 \%$ are highly satisfied, $23.4 \%$ satisfied and $21.4 \%$ somewhat satisfied.

The study found that the bank employees are quite satisfied with their job but the environment in which they work, there exist some lacking that have a tremendous effect on their level of pride for themselves and for the work they are doing.

As the two gender groups, in sampling procedure, were not normally distributed, the most popular Mann-Whitney U test was applied to work out the relationship between gender and job satisfaction with each variable. The study findings in Table - 8 show significantly higher satisfaction among females for promotional opportunities and the work itself. Although Mean Rank of Pay for female is higher than that for male, in the study, it is not statistically significant. The findings also 
indicate that male respondents are more satisfied than female with two facets - interpersonal relations with supervisors and their co-workers. The study is able to prove that higher interpersonal relations with coworkers for male executives is statistically significant but with supervisors is statistically insignificant although ranked higher than those of their female counterpart (Field study shown in Table-8).

\section{Limitations of the study}

The first and most important limitation of the study is in the small sample size and which again is limited only in Chittagong region for ease and convenience. Moreover, the survey covers only officers and above rank. Thus it cannot reflect the all employees engaged in banks. Finally, why and how a particular variable affects job satisfaction has not been investigated in this study.

\section{Conclusion}

The findings of the study indicate that the gender differences in terms five facets of job play a significant role in influencing one's perception of job satisfaction. Furthermore, the present study attempts to enrich the existing knowledge base in the area of job satisfaction in banking sector adding a new dimension of HRM-issues; as there have been very few studies in the context of Bangladesh that have studied gender differences with the employees' perception of job satisfaction. Human resource management practices regardless of gender can be effectively and fairly applied through analyzing more data gathered from respective population and conducting tests on relevant theories to the view point of professional, social and cultural environment.

\section{References and Bibliography}

Bagozzi, R. P., and Yi, Y. (1988). On the Evaluation of Structural Equation Models, Journal of the Academy of Marketing Science, 16 (1): 74-95

Golembiewski, R. G., Yeager, S., (1978). “Testing the Applicability of the JDI to Various Demographic Groups”, Academy of Management Journal, Vol. 21, pp. 514- 519

Hackett, R. D., and Guion, R. M (1985). A Re-evaluation of the AbsenteeismJob satisfaction Relationship. Organizational Behavior and Human Decision Processes, 35, 340-381

Hellriegel, D., Slocum, Jr. W.J., and Woodman, W.R (1995). Organizational Behavior. St. Paul: West Publishing Company. 
Herzberg, F., B. Mausmer, R.O. Peterson, and D. F. Capewell (1957). Job Attitudes: Review of Research and Opinion, Pittsburgh, Pa.: Psychological Service Pittsburgh.

Hussain Md. Moazzam and Jahed Md. Abu. "Women Bank Officers Perception: A study on Nationalized Commercial Banks in Chittagong, The Chittagong University Journal of Commerce, Vol. 15. 2000, pp.103-114

Hulin, C.L., Roznowski, M., and Hachiya, D. (1985). Alternative Opportunities and Withdrawal Decisions: Empirical and Theoretical discrepancies and integration. Psychological Bulletin, 97, 233-250

Hullin, C. L. and P. C. Smith (1965). “ A Lincal Model of Job satisfaction”, Journal of Applied Psychology, Vol. 41, 209-216

Judge, T. A., and Church, A. H. (2000). Job satisfaction, Research and Practice. In C.L. Cooper and E. A. Locke (Eds.) Industrial and Organizational Psychology: Linking Theory with practice (PP. 166- 198). Oxford, UK: Black well

Jung, Kg., Dalessio, A., Johnson, S. M., (1986). "Stability of the Factor Structure of the Job descriptive Index”. Academy of Management Journal, Vol. 29, No.3, pp.609-616

Jurgensen, C. E. (1978). Job Preference (What makes a job good or bad?) Journal of applied Psychology, 63, 267- 276

Kinicki, A. J., Mckee-Ryan, F. M., Schriesheim, C. A., Carson, K. P., (2002) "Assessing the Construct Validity of the Job Description Index: A Review and Meta-Analysis”, Journal of Applied Psychology, Vol. 87, No. 1, pp.14-32

Kohler, S. S and Mathieu, J. E. (1993). An Examination of the Relationship between Affective Reactions, Work Perceptions, Individual Resource Characteristics and Multiple Absence Criteria, Journal of Organizational Behavior, 14, 515-530

Locke, E.A. (1976). "The Nature and Causes of Job Satisfaction in Dunnette, M.D. (Ed), Hand book of Industrial and Organizational Psychology, Rand McNally, Chicago, IL, pp.1297-1343

M. L. Bullen, and G.G. Famholtz, Theoretical and Empirical Investigation of Job Satisfaction and Intended Turnover in Large CPA Firm, Accounting, Organization and Society, 1985, 10(3) , pp . 287-301

Mustafa, H., and Sylvia. R. D., A Factor Analysis Approach to Job satisfaction, Public Personnel Management, 1976, 4. pp.165-172

Okpara, J.O. (2006). "Pay, Promotion, and Job satisfaction in a Sub-Saharan African Economy.” Women in Management Review, Vol.21, No.3, pp.224-240 
Organ Dennis, Hammer Clay. (1982). Organizational Behavior, Business Publication.

Ostroff, C. (1992). The Relationship between Satisfaction, Attitudes, and Performance: An organizational level analysis. Journal of Applied Psychology, 77: 963-974

Putnam. M. L., Improving Employee Relations, Personnel Journal, 1930, 8, pp.314- 325

Robinson L., (1989). Job Attitude Organization: An Exploratory Study, Journal of Applied Social Psychology, 19 : 717

Shamima Tasnim, (Spring 2006). Job Satisfaction among Female Teachers: A Study on Primary Schools in Bangladesh. M. Phil The University of Bergen, Bergen, Norway.

Siddiqui, K. M., Employees' Attitudes and Job Satisfaction, Management Accountant, Quarterly Journal of ICMA Pakistan, Jan - March, 1993, 2(1), p.63

Smith, P. C., Kendall, L.M., Hulin, C. L. (1969). "Measurement of Satisfaction in Work and Retirement”, Rand McNally, Chicago.

\section{$\underline{\text { Appendix Section }}$}

Table 1: Respondents' gender

\begin{tabular}{|c|c|c|c|c|c|}
\hline \multicolumn{2}{|c|}{} & \multicolumn{2}{|c|}{ Sector } & Total & \% \\
\hline \multirow{2}{*}{ Gender } & Male & Private & Public & & \\
\hline Total & Female & 20 & 70 & 180 & 85.7 \\
& & 130 & 10 & 30 & 14.3 \\
\hline
\end{tabular}

Source: Survey data

Table 2: Respondents' working experience in present organization

\begin{tabular}{|c|c|c|c|}
\hline \multirow{2}{*}{ Length of service } & \multicolumn{2}{|c|}{ Gender } & \multirow{2}{*}{ Total } \\
\cline { 2 - 3 } & Male & Female & \\
\hline Less than 1 years & 15 & 6 & 21 \\
1-5 years & 65 & 14 & 79 \\
6-10 years & 62 & 8 & 70 \\
11- 15 or more years & 38 & 2 & 40 \\
\hline Total & 180 & 30 & 210 \\
\hline
\end{tabular}

Source: Survey data 
Table 3: Respondents' working positions

\begin{tabular}{|c|c|c|c|}
\hline \multirow{2}{*}{ Position } & \multicolumn{2}{|c|}{ Gender } & \multirow{2}{*}{ Total } \\
\cline { 2 - 3 } & Male & Female & \\
\hline Executive / Director & 16 & 0 & 16 \\
Senior Management & 62 & 4 & 66 \\
Middle-level Management & 77 & 10 & 87 \\
Officer \& Junior Officer & 25 & 16 & 41 \\
\hline Total & 180 & 30 & 210 \\
\hline
\end{tabular}

Source: Survey data

Table 4: Respondents’ Age group

\begin{tabular}{|c|c|c|c|}
\hline \multirow{2}{*}{ Age in Years } & \multicolumn{2}{|c|}{ Gender } & \multirow{2}{*}{ Total } \\
\cline { 2 - 3 } & Male & Female & \\
\hline Less than 25 years & 14 & 3 & 17 \\
25-35 years & 93 & 20 & 113 \\
35-45 years & 51 & 5 & 56 \\
46 years and above & 22 & 2 & 24 \\
\hline Total & 180 & 30 & 210 \\
\hline
\end{tabular}

Source: Survey data

Table 5: Respondent's educational qualification

\begin{tabular}{|c|c|c|c|}
\hline \multirow{2}{*}{ Qualification levels } & \multicolumn{2}{|c|}{ Gender } & \multirow{2}{*}{ Total } \\
\cline { 2 - 3 } & Male & Female & \\
\hline Below H.S.C / Undergraduate & 0 & 0 & 0 \\
Graduate & 12 & 1 & 13 \\
Post-graduate & 134 & 27 & 161 \\
Hold Additional Degrees like MBM, Banking & 34 & 2 & 36 \\
Diploma, Post Graduate Diploma or Foreign \\
Degrees & & & \\
\hline Total & 180 & 30 & 210 \\
\hline
\end{tabular}

Source: Survey data

Table 6: Marital Status

\begin{tabular}{|l|l|l|l|}
\hline \multirow{2}{*}{ Marital status } & \multicolumn{2}{c|}{ Gender } & \multirow{2}{*}{ Total } \\
\cline { 2 - 3 } & Male & Female & 102 \\
Married & 78 & 24 & 108 \\
Unmarried & 102 & 06 & 210 \\
\hline Total & 180 & 30 & \\
\hline
\end{tabular}

Source: Survey data 
IIUC Studies, Vol. 12

Table7: Frequency and Percentage distribution of respondents at levels of job satisfaction

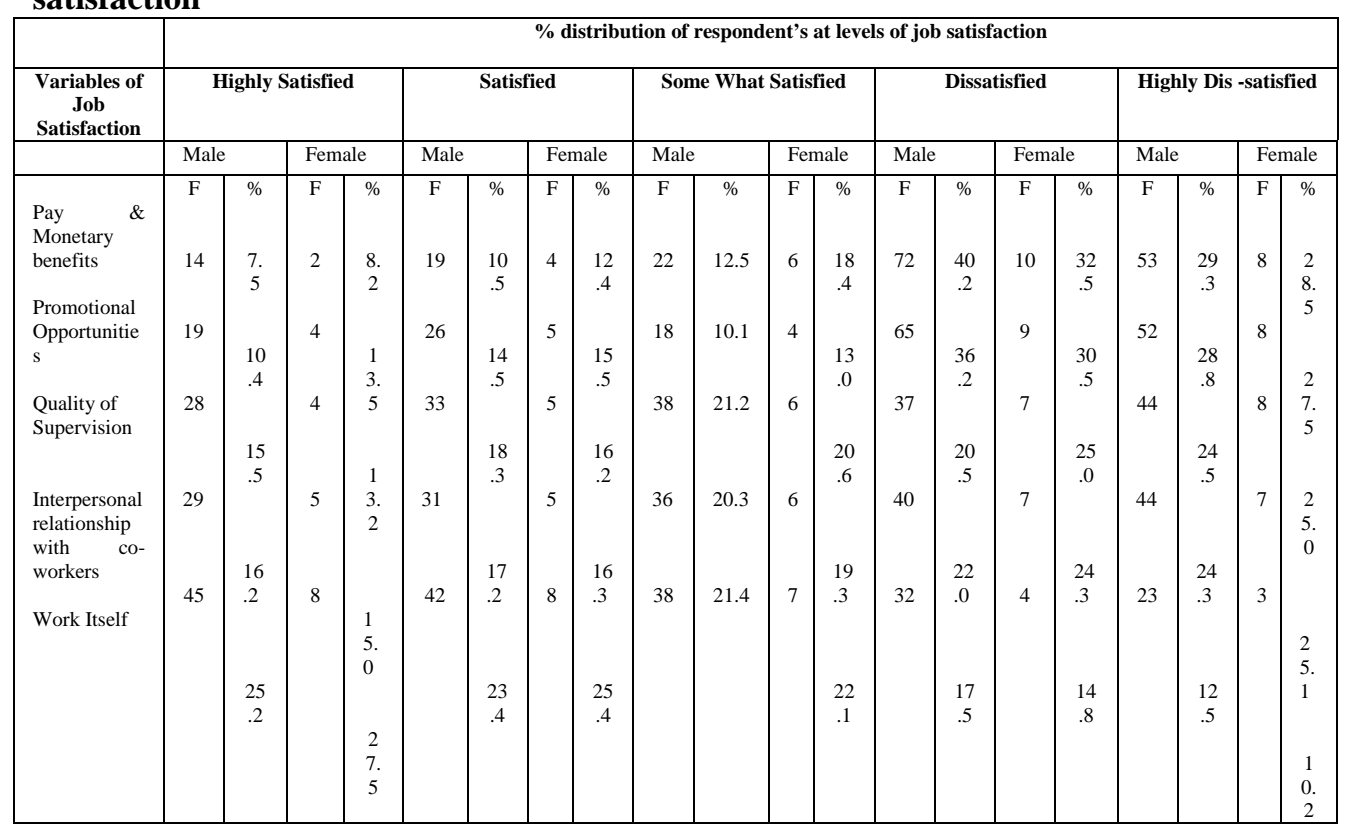

Source: Authors' Calculation on Survey data

Table-8: Mann-Whitney U test For Finding the Relationship between Male \&

Female Bank-executives and overall Job Satisfaction.

\begin{tabular}{|c|c|c|c|c|c|c|}
\hline & $\begin{array}{l}\text { (1) } \\
\text { Pay } \\
\text { (Earnings) }\end{array}$ & $\begin{array}{l}(2) \\
\text { Promotional } \\
\text { Opportunities }\end{array}$ & $\begin{array}{l}\text { (3) } \\
\text { Quality of } \\
\text { supervision }\end{array}$ & $\begin{array}{l}\text { (4) } \\
\text { Co-workers } \\
\text { relationship }\end{array}$ & $\begin{array}{l}\text { (5) } \\
\text { Work } \\
\text { itself }\end{array}$ & $\begin{array}{l}(6) \\
\text { Overall job } \\
\text { satisfaction }\end{array}$ \\
\hline $\begin{array}{l}\text { Mann - } \\
\text { Whitney U }\end{array}$ & 2489.00 & 1807.50 & 2627.50 & 2556.50 & 2033.50 & 2365.50 \\
\hline $\begin{array}{l}\text { Mean rank } \\
\text { Male } \\
\text { Female }\end{array}$ & $\begin{array}{l}100.64 \\
113.62\end{array}$ & $\begin{array}{l}101.43 \\
131.54\end{array}$ & $\begin{array}{l}107.33 \\
105.85\end{array}$ & $\begin{array}{l}124.62 \\
100.28\end{array}$ & $\begin{array}{l}102.31 \\
133.66\end{array}$ & $\begin{array}{l}103.01 \\
115.04\end{array}$ \\
\hline $\begin{array}{ll}\text { Sum } & \text { of } \\
\text { ranks } & \\
\text { Male } & \\
\text { Female } & \\
\end{array}$ & $\begin{array}{r}18,115.2 \\
3,408.6\end{array}$ & $\begin{array}{l}18,257.4 \\
3,946.2\end{array}$ & $\begin{array}{l}19,319.4 \\
3,175.5\end{array}$ & $\begin{array}{l}22,431.6 \\
3,008.4\end{array}$ & $\begin{array}{l}18,415.8 \\
4,009.8\end{array}$ & $\begin{array}{l}18,541.8 \\
3,451.2\end{array}$ \\
\hline $\mathrm{Z}$ & -0.594 & -2.414 & -0.126 & -1.346 & -1.876 & -0.655 \\
\hline $\begin{array}{l}\text { Significance } \\
\text { (two-tailed) }\end{array}$ & 0.682 & $0.006 *$ & 0.811 & $0.005^{*}$ & $0.014 *$ & 0.512 \\
\hline
\end{tabular}

*indicates significant at 0.05 level

Source: Authors' Calculation on Survey data 